\title{
Consumption of medicines among adolescent students: a concern
}

\author{
Clécio H. da Silva, ${ }^{1}$ Elsa R. J. Giugliani ${ }^{2}$
}

\begin{abstract}
Objective: To study the prevalence of medicine consumption among adolescents students and to correlate it with school type (public or private), grades and school shift, age and gender of the students, education level of the parents and family habit of medicine consumption.

Methods: This is a cross-sectional study with a representative sample of the school population attending high school in Porto Alegre: 1,281 students from 58 groups, distributed in proportional strata of public and private schools. The questionnaire was answered individually and anonymously by the students inside of the classroom. The students provided information about their consumption of medicines during the seven previous days, specifying the kind of medicine used. Descriptive analysis of the variables, linear association and multiple logistic regression tests were used.

Results: The use of medicines occurred in $49.5 \%$ of the sample. The most consumed pharmacological groups were analgesics/anti-inflammatories and anti-gout agents (32.5\% of the consumption), and hormones and similar (12.1\%). Analgesics/antipyretics/anti-inflammatories and estrogens/ progestogens were, respectively, the most consumed medicines of the pharmacological groups above mentioned. Aspirin was the most consumed analgesic substance. Female students $(R C=2.24), 17$ years old or over $(R C=1.41)$, with low maternal education $(R C=1.40)$, and whose relatives have the habit of consuming medicines $(R C=1.39)$, presented increased risk for medicine consumption.

Conclusions: It was found that the consumption of medicines is high among school adolescents, especially among girls and older students. Family habit of consumption and low maternal education also favor the use of medicines.
\end{abstract}

J Pediatr (Rio J). 2004;80(4):326-32: Medicine use, students, adolescence.

\section{Introduction}

Medication use has grown dramatically in both industrialized and developing countries. ${ }^{1}$ The indiscriminate use of medications, especially without medical advice, produces some direct and indirect effects on individuals, becoming a serious public health problem.

1. M.Sc.; Associate professor, Department of Pediatrics, School of Medicine, Universidade Luterana do Brasil (ULBRA), Canoas, RS, Brazil.

2. Ph.D.; Associate professor, Department of Pediatrics and Child Care, Universidade Federal do Rio Grande do Sul (UFRGS), Porto Alegre, RS, Brazil.

* This article was written based on the Master's dissertation by the $1^{\text {st }}$ author in the Graduate Program in Medicine: Pediatrics of Universidade Federal do Rio Grande do Sul (UFRGS).

Manuscript received Oct 17 2003, accepted for publication Mar 312004.
Even though only $50 \%$ of the Brazilian population has access to medications, their use is widespread among individuals of all age groups, placing Brazil among the world's biggest consumers (5th in the rank). ${ }^{2}$ Several factors contribute to this scenario: difficult access to health services; an inappropriate drug surveillance system (which allows the proliferation of drugstores that sell nonprescription medications); mercantilization of medications; and habit of taking drugs to control anxiety or problems with no apparent organic cause. The improper use of medications is also influenced by social factors: desire for better healthcare, availability of products, morbidity patterns of different population groups and pressure from chemical and pharmaceutical manufacturers directly on consumers or on health professionals. ${ }^{3}$ 
Specific studies should be conducted on the consumption of medications to assess whether their use is justifiable and whether there are some factors influencing their use. Population-based studies, especially with children, 1,9-11 describing drug utilization patterns are scarce in Brazil. ${ }^{4-9}$ Most of these studies indicate that children are more susceptible to taking medicines and that these medicines are mostly prescribed by physicians. ${ }^{9,12}$ Some studies show that medications are used differently, depending on the gender 9,13 and socioeconomic status of individuals $9,14,15$ However, studies that assess the use of medications among adolescents are nonexistent. This age group is characterized by the development of individual cognitive judgment and capacity, which may independently influence the results of some studies. On top of that, this group has a high consuming potential and has become the target of advertising campaigns, including medication ads.

The present study assessed the prevalence of medication use among adolescents, showing the most commonly used drugs, in addition to evaluating some factors that may influence their use.

\section{Methods}

A cross-sectional study was carried out with 56,520 high school students from public (municipal, state and federal) and private schools of Porto Alegre, selected from the list of schools provided by the State Department of Culture and Education of Rio Grande do Sul (SEC/RS). The minimal sample size was calculated using a $99.9 \%$ confidence interval and an acceptable error of $5 \%$, resulting in 1,293 students. Considering possible losses and in an attempt to have a better accuracy, the interview was applied to around 1,500 students. Using a systematic sampling method, the clusters of student groups included: 41 groups from state schools ( 809 students); two groups from federal schools ( 52 students); two groups from municipal schools ( 23 students) and 13 groups from private schools (427 students). The proportionality of groups in the population was maintained in the sample.

The study was approved by the State Department of Culture and Education of Rio Grande do Sul and by school principals. In the classroom, after proper consent, a questionnaire was handed out to students, who answered it individually and anonymously within an average of 30 minutes under the supervision of a previously trained interviewer. Students older than 20 were excluded from the study. The use of medications on the seven days that preceded the interview was assessed by a yes-or-no question. If the answer was affirmative, respondents were asked to specify the name of the drug, classified into 16 large therapeutic groups, and main groups and subgroups according to the Pan American Health Organization (PAHO) classification system. ${ }^{16}$ The "report of medication use" variable indicates the use of a given medication; in this case, the same student could have more than one report of medication use if he/she used more than one drug.
The following variables were analyzed: age and gender, parental educational level, person who advised the medication use, type of school (public or private), grade and time of day attended. The habit of medication intake among family members who shared the same household was also taken into account.

A preliminary descriptive analysis of the dependent variable (medication use) and of independent variables was made, and association tests (chi-square) were later applied. Variables correlated with medication use ( $p \alpha<0.2)$ were included in the multiple logistic regression model, and the odds ratios and their respective confidence intervals were calculated. Epi-Info (version 6.3) and SPSS for Windows (version 10.0) were used for the statistical analysis.

The study was regarded as being of low risk to human beings ${ }^{17}$ according to international standards regulated by the Brazilian Ministry of Health. The study protocol was approved by the Scientific Committee and the Research Ethics Committee of Hospital de Clínicas de Porto Alegre (HCPA).

\section{Results}

The initial sample size consisted of 1,597 students, but 73 were excluded as they were older than 20 years. Of the remaining 1,524 students, $210(13.8 \%)$ did not show up on the day of the interview, $30(2 \%)$ did not answer the question about medication use on the last seven days, and another three lost their questionnaires $(0.2 \%)$, which resulted in a $16 \%$ loss. Therefore, the final sample size consisted of 1,281 students. Mean age was $16.2 \pm 1.4$ years [ $14-20$ years], and female students constituted 58.2 of the sample versus $41.8 \%$ of male students. Most students attended junior high school (1st year) in the morning (Table 1). Most of the parents had finished high school ( $81.1 \%$ of fathers and $81.9 \%$ of mothers of students in private schools, and $49.7 \%$ of fathers and $43.6 \%$ of mothers of students in public schools).

Table 1 - Distribution of the sample according to grade and school shift - Porto Alegre (RS), Brazil

\begin{tabular}{lccc}
\hline & Students & Percentage & No. of Classes \\
\hline Grade & & & \\
1st & 450 & 35.1 & 15 \\
2nd & 320 & 25.0 & 13 \\
3rd & 252 & 19.7 & 8 \\
4th* & 25 & 1.9 & 1 \\
SSE $^{\dagger}$ & 234 & 18.3 & 21 \\
Shift & & & \\
$\quad$ Morning & 863 & 67.4 & 35 \\
$\quad$ Afternoon & 169 & 13.2 & 7 \\
$\quad$ Evening & 249 & 19.4 & 16 \\
Total & 1,281 & & 58 \\
\hline
\end{tabular}

* In technical high schools there is a 4th grade.

† SSE = Specific subject enrolment (available in some public schools during the period the study was carried out). 
Medication use seven days prior to the interview was present in $49.5 \%$ of the sampled population. The most commonly used medications included painkillers/antiinflammatory drugs/antigout drugs $(32.5 \%)$, followed by hormones and similar drugs (12.1\%) and drugs that act upon the autonomous nervous system (11.6\%) - Table 2 . When the main and more specific groups were considered, the most frequently used medications included painkillers/ antipyretics/anti-inflammatory drugs and sympathomimetics. Acetylsalicylic acid and derivatives were the most common painkillers/antipyretics/antiinflammatory drugs, followed by para-aminophenol derivatives and pyrazolones and pyrazolidinodiones. The major substances included acetylsalicylic acid, paracetamol and sodium dipyrone. With regard to hormones and analog drugs, the most commonly used ones were estrogens/progestins and corticosteroids. Among the medications that act on the autonomous nervous system, sympathomimetics, especially alpha-adrenergic stimulants, were the most widely used. The major substances included naphazoline chlorhydrate and isometheptene chlorhydrate. In terms of prevalence, that of painkillers amounted to $24.3 \%$, compared to $7.9 \%$ for sympathomimetics and estrogens/progestins, among girls, amounted to $10.2 \%$.

Bivariate analyses showed a significantly more widespread ( $p \alpha<0.05$ ) use of medications among female students attending senior high school (last year), students attending classes during the day, whose family members had the habit of medication intake and whose mothers had a lower educational level. Age, paternal education, and type of school did not show any statistically significant association (Table 3 ).
The multivariate analysis, using a logistic regression model, demonstrated that female students had 2.2 times greater odds of using medications than male students; students whose family members had the habit of taking medications showed a 1.4 times greater likelihood of using them, as well as students aged 17 or older. With regard to the level of maternal education, the students whose mothers had no more than elementary school education had a $40 \%$ higher chance of using medication (Table 4). In order to assess whether the use of oral contraceptives was responsible for the more widespread medication use among female adolescents and older students, we repeated the analysis excluding this type of drug. The association between the more widespread use of medications and female adolescents was maintained ( $\mathrm{OR}=1.87-95 \% \mathrm{CI}: 1.45-2.41)$, as well as that among students aged 17 or older (OR $=1.54-95 \% \mathrm{CI}$ : 1.14-2.08).

There was a widespread use of medications among family members $(66.1 \%)$, and mothers were the ones who used medications more frequently (Table 5). We also noted that out of 971 reports of medication use on the last seven days, $53.2 \%$ did not have a prescription, and in this case, mothers were the ones who more often recommended the use of that medication (42.5\%), whereas self-medication occurred in $12.3 \%$ of the students (Table 6 ).

\section{Discussion}

In the present study, the prevalence of medication use on the last seven days prior to the interview was quite high among the students. Nearly half of them used medications. Studies that assess the specific use of medications among adolescents utilizing a seven-day recall period are not

Table 2 - Prevalence of medication use seven days prior to the interview among high school students according to the Pan American Health Organization (PAHO) classification system - Porto Alegre (RS), Brazil

\begin{tabular}{|c|c|c|c|c|c|c|c|c|}
\hline Large groups & $\mathbf{f}$ & $\% *$ & Main groups & $\mathbf{f}$ & $\% *$ & Main subgroups & $\mathbf{f}$ & $\% *$ \\
\hline $\begin{array}{l}\text { Painkillers/anti-inflammatories/ } \\
\text { antigout drugs }\end{array}$ & 316 & 24.7 & $\begin{array}{l}\text { Painkillers/antipyretics/ } \\
\text { anti-inflammatories }\end{array}$ & 312 & 24.3 & $\begin{array}{l}\text { Acetylsalicylic acid and } \\
\text { derivatives (eg., ASA) } \\
\text { Para-aminophenol derivatives } \\
\text { (eg., paracetamol) } \\
\text { Pyrazolones and pyrazolidinodiones } \\
\text { (eg., dipirona) }\end{array}$ & $\begin{array}{l}137 \\
78 \\
51\end{array}$ & $\begin{array}{l}10.7 \\
6.1 \\
4.0\end{array}$ \\
\hline Hormones and analogous & 118 & 9.2 & $\begin{array}{l}\text { Eestrogens/progestins } \\
\text { Corticosteroids } \\
\text { Other }\end{array}$ & $\begin{array}{c}76 \\
35 \\
7\end{array}$ & $\begin{array}{l}5.9 \\
2.7 \\
0.5\end{array}$ & & & \\
\hline $\begin{array}{l}\text { Drugs that act upon the } \\
\text { autonomous nervous system }\end{array}$ & 113 & 8.8 & $\begin{array}{l}\text { Sympathomimetics } \\
\text { Other }\end{array}$ & 101 & 7.9 & $\begin{array}{l}\text { Alpha-adrenergic stimulants } \\
\text { (eg., naphazoline chlorhydrate) } \\
\text { Other sympathomimetics } \\
\text { (eg., isometheptene chlorhydrate) } \\
\text { Beta-adrenergic stimulants } \\
\text { (eg., albuterol) }\end{array}$ & $\begin{array}{l}51 \\
26 \\
22\end{array}$ & $\begin{array}{l}4.0 \\
2.0 \\
1.7\end{array}$ \\
\hline
\end{tabular}

* Percentage among students. 
Table 3 - Bivariate analysis between use of medications in the previous 7 days and the characteristics of the sample - Porto Alegre (RS), Brazil

\begin{tabular}{|c|c|c|c|}
\hline \multirow{2}{*}{ Characteristics of the sample } & \multicolumn{2}{|c|}{ Use } & \multirow[t]{2}{*}{$\mathbf{p} \alpha$} \\
\hline & $\mathbf{f}$ & $\%$ & \\
\hline \multicolumn{4}{|l|}{ Sex* } \\
\hline Male $(n=533)$ & 205 & 38.5 & \\
\hline Female $(n=743)$ & 428 & 57.6 & 0.001 \\
\hline \multicolumn{4}{|l|}{ Age* } \\
\hline Younger than 17 years old $(n=778)$ & 373 & 47.9 & \\
\hline 17 years old or older $(n=500)$ & 260 & 52.0 & 0.174 \\
\hline \multicolumn{4}{|l|}{ School } \\
\hline Public $(n=860)$ & 419 & 48.7 & \\
\hline Private $(n=421)$ & 215 & 51.1 & 0.465 \\
\hline \multicolumn{4}{|l|}{ Grade } \\
\hline 1 st $(n=450)$ & 210 & 46.7 & \\
\hline 2nd $(n=320)$ & 156 & 48.8 & \\
\hline $3 r d(n=252)$ & 148 & 58.7 & \\
\hline 4 th/SSE ${ }^{\dagger}(n=259)$ & 120 & 46.3 & 0.011 \\
\hline \multicolumn{4}{|l|}{ Shift } \\
\hline Evening $(n=249)$ & 103 & 41.4 & \\
\hline $\begin{array}{l}\text { Day - morning and afternoon } \\
(n=1,032)\end{array}$ & 531 & 51.5 & 0.005 \\
\hline \multicolumn{4}{|l|}{ Mother's educational level* } \\
\hline $\begin{array}{l}\text { Incomplete high school or lower } \\
(n=697)\end{array}$ & 369 & 52.9 & \\
\hline $\begin{array}{l}\text { High school or college degree } \\
(n=540)\end{array}$ & 251 & 46.5 & 0.028 \\
\hline \multicolumn{4}{|l|}{ Father's educational level* } \\
\hline $\begin{array}{l}\text { Incomplete high school or lower } \\
(n=723)\end{array}$ & 376 & 52.0 & \\
\hline $\begin{array}{l}\text { High school or college degree } \\
(n=474)\end{array}$ & 228 & 48.1 & 0.207 \\
\hline \multicolumn{4}{|l|}{ Family medication use* } \\
\hline No $(n=427)$ & 188 & 44.0 & \\
\hline Yes $(n=831)$ & 437 & 52.6 & 0.005 \\
\hline
\end{tabular}

available in the literature. Medication use by children of different ages was investigated in two studies conducted in Pelotas, state of Rio Grande do Sul, Brazil, where prevalence rates of 65 and $68 \%$ were observed in infants within the first and third months of life, respectively, ${ }^{9}$ and rates of $55.8 \%$ were found for those within 35 and 53 months of life. ${ }^{15} \mathrm{~A}$ Spanish study 18 with children aged less than 15 years revealed a medication use of $25.4 \%$. These differences may be partly explained by the different age groups analyzed and by distinct recall periods ( 15 days in the first two Brazilian studies and two days in the Spanish study). A Dutch study that assessed the use of medications in infants and children aged between 0 and 16 years showed that the use of medications was widespread in early childhood, decreased during the school years and increased again in adolescence, and that approximately $60 \%$ of the studied population had used at least one medication in that year. ${ }^{19}$

Basically one third of the medications used consisted of painkillers/anti-inflammatory drugs/antigout drugs. The widespread use of painkillers (24.7\%) also was observed in African adolescents who attended high school and in Dutch children - $10 \% .{ }^{19,20}$ It is argued whether an organic substrate could be involved in the genesis of pain in all of these cases. Very likely, emotional factors may be involved. Moreover, painkillers are easily obtained from grocery outlets, pharmacies and drugstores, also being available from "home pharmacies" or even from schools. There are massive advertising campaigns for the use of painkillers; in addition, they are the type of medication more often recommended by family members or friends.

Among hormones and similar drugs (second most widely used type of medications), estrogens/progestins (10.2\%) were the most frequently used. The use of contraceptives, considering women younger than 20 years, is compatible with the reality in which adolescents are included. A study carried out with high-school students in public schools of São Paulo ${ }^{21}$ revealed that sexual life began at 15.7 years,

Table 4 - Variables that show association with the use of medications by high school students in the previous 7 days, a multivariate analysis - Porto Alegre (RS), Brazil

\begin{tabular}{|c|c|c|}
\hline Variables & $\begin{array}{l}\text { Odds ra } \\
(95 \%)\end{array}$ & $\begin{array}{l}\text { (adjo and Confidence interval } \\
\text { (adjusted) }\end{array}$ \\
\hline \multicolumn{3}{|l|}{ Sex } \\
\hline Male & 1.00 & - \\
\hline Female & 2.24 & $1.75-2.87$ \\
\hline \multicolumn{3}{|l|}{ Age } \\
\hline$<17$ years old & 1.00 & - \\
\hline$\geq 17$ years old & 1.41 & $1.06-1.87$ \\
\hline \multicolumn{3}{|l|}{ Mother's educational level } \\
\hline High school or college degree & 1.00 & - \\
\hline Incomplete high school or lower & 1.40 & $1.09-1.78$ \\
\hline \multicolumn{3}{|l|}{ Family medication use } \\
\hline No & 1.00 & - \\
\hline Yes & 1.39 & $1.08-1.77$ \\
\hline
\end{tabular}


Table 5 - Family habit of use of medications among adolescent students - Porto Alegre (RS), Brazil

\begin{tabular}{lcc}
\hline Family habit of use of medication* & $\mathbf{f}$ & $\mathbf{\%}$ \\
\hline Absent & 427 & 33.9 \\
Present & 831 & 66.1 \\
$\quad$ Mother & 401 & 48.2 \\
Father & 256 & 30.8 \\
Grandparents & 131 & 15.8 \\
Siblings & 85 & 10.2 \\
Uncles/aunts & 18 & 2.2 \\
Others & 21 & 2.5 \\
$\quad$ Subtotal & $912 \dagger$ & 109.7 \\
Total & 1.258 & 100.0 \\
\hline
\end{tabular}

* 23 students did not provide the information.

$\dagger \mathrm{n}>831$ due to concomitant use of medication by more than one member of the family.

Table 6 - Recommendation of use of medications among high school students Porto Alegre (RS), Brazil

\begin{tabular}{|c|c|c|}
\hline Recommendation* & f & $\%$ \\
\hline Medical & 453 & 46.6 \\
\hline Non-medical & 518 & 53.2 \\
\hline Mother & 220 & 42.5 \\
\hline Self-medication & 64 & 12.3 \\
\hline Father & 43 & 8.3 \\
\hline Friend & 27 & 5.2 \\
\hline Others $^{\dagger}$ & 80 & 15.4 \\
\hline Unknown & 98 & 18.9 \\
\hline Subtotal & $532^{\ddagger}$ & 102.6 \\
\hline Total & 971 & 100.0 \\
\hline
\end{tabular}

* 23 students did not provide the information.

$\dagger$ Others include grandparents, uncles/aunts and siblings.

$\ddagger \mathrm{n}>518$ due to concomitant recommendation of more than one member of the family.

whereas in the state of Pernambuco, ${ }^{22} 31.6 \%$ of university students had already their first sexual relationship by the age of 19 .

The use of glucocorticoids $(2.7 \%)$ is noteworthy. The use of these medications may be explained by the high frequency of allergic respiratory diseases in Rio Grande do Sul. A study conducted with students attending elementary school (5th to 8th grades), aged between 10 and 18 years, in Porto Alegre, showed a $22 \%$ prevalence of current asthma (more predominant among female students) and a $50.1 \%$ prevalence of atopic disease. ${ }^{23}$

The use of medications that act upon the autonomous nervous system by high-school students occupies the third place. Isometheptene chlorhydrate, the second most widely used substance in this group, is often used to treat headaches, and can be easily obtained from pharmacies and drugstores. It should be underscored that headaches are common complaints that often have a psychosomatic etiology.
The use of medications was more frequent among female students, which is in agreement with the results of most studies. ${ }^{13,24,25-28}$ The stress and anxiety caused by the multiple roles taken on by women inside and outside the home, which many times begin during adolescence, are possible reasons for the frequent use of medications in this group. Furthermore, women seek medical care, show their feelings, have depressive symptoms and hospital admissions more often than men do. ${ }^{24}$ All of these factors may contribute to the widespread use of medications by women.

Medications also were frequently used by students whose family members had the habit of taking medicines. Here we may see the influence of family environment on the use of medications, either directly or by the example given by family members. Family use of medications (65.6\%) was widespread especially among mothers and may inadvertently and unconsciously convey the idea that the use of medications is something normal, part of everyday life. ${ }^{15}$ 
The present study also showed that the level of maternal education influences the use of medications by adolescents. We take for granted that mothers with a better level of education are much more aware of medication use by their children since they have easier access to information and health services.

Lack of medical advice regarding the use of medications by adolescents is worrying; virtually twice as high as that which was observed in Lisbon and Porto, in Portugal. ${ }^{29}$ In the absence of medical advice, mothers are the ones who most frequently indicate the medications to be used, reflecting their role in providing and protecting their children, who usually depend on their mothers when it comes to health issues.

Some methodological aspects of this study should be discussed. According to some authors, the ideal recall period would be 24 hours, which would reduce the recall bias. 9,30 However, the recall period employed in studies on medication use in childhood has ranged from two to 14 days. ${ }^{9,15,18}$ In the present study, the choice for seven days was an attempt to assess medication use on every weekday, also including weekends, when students are outside the school and closer to the family environment.

Another important aspect is concerned with the representativeness of the sample in terms of the whole population of adolescents of Porto Alegre. Based on data from the Brazilian Institute of Geography and Statistics (IBGE) and on the list of students enrolled in high schools, we estimated that $42 \%$ of the population aged between 14 and 19 years were attending school in the year in which the study was carried out. Therefore, definitive conclusions about the use of medications among adolescents should be made with caution, since adolescents who had a lower socioeconomic status may have been left out of this study. Possibly, the use of medications by adolescents is more widespread than the one reported in the present study, as those adolescents who had not been enrolled in school may be raised by mothers with a lower level of education, and may consequently be influenced to use medications more frequently.

The results obtained in the present study challenge everyone to become more aware of medication use problems. The burden of responsibility must be shared by everyone. The role of family, school, health professionals and health authorities is of utmost importance for the implementation of measures that may tackle this health problem in a more efficient way. For changes to be made, all segments of society should bear the responsibility of reassessing, educating, rationalizing and raising awareness about the use of medications and its relationship with health issues. This is one of the most sensible ways to eliminate the indiscriminate use of medications and allow that these medications be used only as an essential tool in promoting a better quality of health and well-being for the population.

\section{References}

1. Simões MJ, Farache Filho A. Consumo de medicamentos em região do Estado de São Paulo (Brasil), 1985. Rev Saúde Públ. 1988;22:494-9.

2. Schenkel EP. Cuidados com os medicamentos. Porto Alegre (RS)/Florianópolis (SC): Editora da Universidade - UFRGS/ Editora da UFSC; 1996.

3. Lunde PKM, Baksaas I. Epidemiology of drug utilization: basic concepts and methodology. Acta Med Scand. 1988;721:7-11.

4. Cordeiro H. A indústria da saúde no Brasil. Rio de Janeiro (RJ): Graal; 1980.

5. Giovanni G. A questão dos remédios no Brasil (produção e consumo). São Paulo (SP): Polis; 1980.

6. Béria JU, Victora CG, Brancher A. Consumo de medicamentos em três grupos sociais. Revista da Semana Acadêmica da Medicina da UFPel. 1980;4:51-9.

7. Barros MBA. Saúde e classe social: um estudo sobre morbidade e consumo de medicamentos [tese]. Ribeirão Preto (SP): Faculdade de Medicina - USP; 1983.

8. Cabral de Barros JA. A medicalização da clientela previdenciária. [dissertação]. São Paulo (SP): Universidade de São Paulo; 1982.

9. Weiderpass E. Epidemiologia do consumo de medicamentos no primeiro trimestre de vida em centro urbano do Brasil. [dissertação]. Pelotas (RS): Universidade Federal de Pelotas; 1994.

10. Haak H. Pharmaceuticals in two Brazilian villages: lay practices and perceptions. Soc Sci Méd. 1988;27:1415-27.

11. Béria JU, Victora CG, Barros FC, Teixeira AB, Lombardi C. Epidemiologia do consumo de medicamentos em crianças de centro urbano da região sul do Brasil. Rev Saúde Públ. 1993;27:95-104.

12. Kovar MG. Use of medication and vitamin-mineral supplements by children and youths. Publ Health Reports 1985;100:470-3.

13. Rylance GW, Woods CG, Cullen RE, Rylance ME. Use of drugs by children. BMJ. 1988;297:445-7.

14. Laurell AS. Social analysis of collective health in Latin America. Soc Sci Méd. 1989;28:1183-91.

15. Béria JU. Epidemiologia do consumo de medicamentos em crianças de Pelotas, RS, Brasil: remédio não é brinquedo. [tese]. Porto Alegre (RS): Universidade Federal do Rio Grande do Sul; 1991.

16. Organización Panamericana de la Salud. Clasificacion Internacional de Medicamentos. Programa Regional de Medicamentos Esenciales de la Organización Panamericana de la Salud (propuesta). Washington, DC: OPS; 1987.

17. Goldim JR. Pesquisa em saúde: leis, normas e diretrizes. $2^{a}$ ed. Porto Alegre (RS): Hospital de Clínicas de Porto Alegre (HCPA); 1995.

18. Rajmil L, Ruiz C, Segú JL, Fernandez E, Segura A. Factores asociados al consumo de medicamentos em la población infantil. Med Clin (Barc). 2000;114:214-6.

19. Schirm E, van den Berg $P$, Gebben $H$, Sauer $P$, De Jong-van Berg $\mathrm{L}$. Drug use of children in the community assessed through pharmacy dispensing data. Br J Pharmacol. 2000;50:473-8.

20. Abiodun OA, Adelekan ML, Ogunremi OO, Oni GA, Obayan AO. Pattern of substance use amongst secondary school students in Ilorin, northern Nigeria. West Afr J Méd. 1994;13:91-7.

21. Scivoletto S, Tsuji RK, Abdo CHN, Queiróz S, Andrade AG, Gattaz WF. Relação entre consumo de drogas e comportamento sexual de estudantes de $2^{\circ}$ grau de São Paulo. Rev Bras Psiquiatr. 1999;21:87-94.

22. Carneiro RM, Ludemir, AB, Duarte MSM, Moreira MFA, Campelo DEC, Melo LMP. Comportamento de risco para AIDS entre estudantes universitários: experiência da UFPE. Anais da Faculdade de Medicina da Universidade Federal de Pernambuco. 1999;44:113-7.

23. Fiore RW, Comparsi AB, Reck CL, Oliveira JK, Pampanelli KB, Fritscher CC. Variação na prevalência de asma e atopia em um grupo de escolares de Porto Alegre, Rio Grande do Sul. J Pneumol. 2001;27:237-42. 
24. Rosenfeld S. Prevalência, fatores associados e mau uso de medicamentos entre idosos: uma revisão. Cad Saúde Públ. 2003; 19:717-24.

25. Ledoux S, Choquet M, Manfredi R. Self-reported use of drugs for sleep or distress among French adolescents. J Adolesc Health. 1994;15:495-502.

26. Guiot ER, Bautista CF, Mora MEM, Morón MLA, Rodríguez MD. Consumo de alcohol y drogas en estudiantes de Pachuca, Hidaldo. Salud Públ Méx. 1999;41:297-308.

27. Muza GM, Bettiol H, Muchillo Gl, Barbieri MA. Consumo de substâncias psicoativas por adolescentes escolares de Ribeirão Preto, SP (Brasil). I - Prevalência de consumo por sexo, idade e tipo de substância. Rev Saúde Públ. 1997;31:21-9.

28. Genovés JS, Larrea VP, Gomis ER, Martinez-Mir I. Consumo de hierbas medicinales y medicamentos. Atencion Primaria. 2001;28:311-4.
29. Martins AP, Miranda Ada C, Mendes $Z$, Soares MA, Ferreira $P$, Nogueira A. Self-medication in a Portuguese urban population: a prevalence study. Pharmacoepidemiol Drug Saf. 2002;11: 409-14.

30. van der Geest S, Hardon A. Drugs use: methodological suggestions for field research in developing countries. Health Pol Plan. 1988;2:152-8.

Corresponding author:

Clécio Homrich da Silva

Rua Eça de Queiroz, 220/305

CEP 90670-020 - Porto Alegre, RS, Brazil

Tel./Fax: + 55 (51) 3333.1527

E-mail: clecio.homrich@terra.com.br 